\title{
21-1 Redesigning EU Fiscal Rules: From Rules to Standards
}

\author{
Olivier Blanchard, Álvaro Leandro, and Jeromin Zettelmeyer \\ February 2021
}

\begin{abstract}
The European Union's fiscal rules have been suspended until at least the end of 2021. When they are reinstated, they will need to be modified, if only because of the high levels of debt. Proposals have been made-and more are to comesuggesting various changes and simplifications.
\end{abstract}

In this paper, we take a step back and discuss how one should think about debt sustainability in the current and likely future EU economic environment. We argue that, given the complexity of the answer, it is an illusion to think that EU fiscal rules can be simple. But it is also an illusion to think that they can ever be complex enough to accommodate most relevant contingencies.

This leads us to propose the abandonment of fiscal rules in favor of fiscal standards, i.e., qualitative prescriptions that leave room for judgment together with a process to decide whether the standards are met. Central to this process would be country-specific assessments using stochastic debt sustainability analysis, led by national independent fiscal councils and/or the European Commission. Disputes between member states and the European Commission on application of the standards should preferably be adjudicated by an independent institution, such as the European Court of Justice (or a specialized chamber), rather than by the Council of the EU.

JEL codes: E62, F42, H6O, H61, H62, H63

Keywords: interest rates, fiscal policy, public debt, primary balance, fiscal deficit, fiscal rules, fiscal governance, fiscal standards, debt sustainability analysis

Olivier Blanchard is C. Fred Bergsten Senior Fellow at the Peterson Institute for International Economics and Robert M. Solow Professor of Economics emeritus at MIT. Álvaro Leandro is an economist at CaixaBank Research. Jeromin Zettelmeyer is deputy director of the International Monetary Fund's Strategy, Policy, and Review Department and the Dennis Weatherstone Senior Fellow at the Peterson Institute for International Economics (on leave).

The views expressed in this paper are those of the authors and do not represent the views of the IMF, its executive board, IMF management, or CaixaBank. 
Authors' Note: This project was started while Leandro and Zettelmeyer were junior and senior fellows, respectively, at the Peterson Institute for International Economics. A draft was circulated and presented before the COVID-19 crisis. The crisis forced rethinking, and this is a largely new draft. The previous draft considered three dimensions of reform: shift from rules to standards, treatment of public investment, and policy implications of demand externalities. This draft focuses on the first, which we see as the most central.

We are very grateful to Nathaniel Arnold, Bergljot Barkbu, Philip Barrett, Roel Beetsma, Agnès Bénassy-Quéré, Wolfgang Bergthaler, Laurence Boone, Jocelyn Boussard, Marco Buti, Maria Coelho, Jérémie Cohen-Setton, Grégory Claeys, James Daniel, Davide Debortoli, Paolo Dudine, Selim Elekdag, Harald Finger, Clemens Fuest, Joseph Gagnon, Vítor Gaspar, Anna Gelpern, Daniel Gros, Sebastian Grund, Nikolay Gueorguiev, Sean Hagan, Richard Hughes, Olivier Jeanne, Yosuke Kido, Jacob Kierkegaard, Emmanouil Kitsios, Yair Listokin, Erik Lundback, Michael McMahon, Rui Mano, Philip Mohl, Dirk Muir, Christian Odendahl, Catherine Pattillo, Jean Pisani-Ferry, Hélène Poirson, Mahmood Pradhan, Ernesto Reitano, Werner Roeger, Karl Scerri, David Super, Guido Tabellini, Niels Thygesen, Alexander Tieman, Elif Ture, Ángel Ubide, Henk Van Noten, Nicolas Véron, Hauke Vierke, Jakob von Weizsäcker, Chris White, Thomas Wieser, David Wilcox, Guntram Wolff, Charles Wyplosz, and Susan Yan for helpful conversations and comments on an earlier draft; to Leland Smith for preparing a survey of the legal literature on rules versus standards; and to conference or seminar participants at Georgetown Law School, the European Commission, the European Central Bank, and the IMF for helpful comments. We are also grateful to the editor and the four referees of Economic Policy for their detailed comments and suggestions on an earlier draft and to participants at the 72nd Economic Policy special panel meeting, October 2020, for additional comments. 


\section{INTRODUCTION}

There are two dimensions to the European Union's fiscal framework. The first relates to the development of a fiscal union, through increased risk sharing, common borrowing, and the size and use of the common EU budget. The second focuses on the design and application of EU-level fiscal rules to national fiscal policies.

The COVID-19 crisis has led to movement on the first, with the creation of a recovery fund. It has also led to a suspension of the fiscal rules, until at least the end of 2021.

The two dimensions are related, but largely independent. In this paper we focus only on the second dimension, the design of EU fiscal rules, under the assumption that the scope of fiscal union may grow but will remain limited.

The challenges are clear: The rules were designed to achieve low debt levels in an environment of positive interest rates. The post-COVID-19 reality is one of high debt levels, but likely very low interest rates for some time to come. If and when the rules are reinstated, what should they look like?

One approach is incremental reform, perhaps with an adjustment of the target debt level, or at least of the speed at which it should be reached, together with a simplification of the general framework and a more prominent role for an expenditure rule.

We argue for a more ambitious approach. Going back to first principles, we contend that incremental reform will not be enough. No quantitative rule can hope to come close to fitting the diversity of possible country-time situations. Simplicity is attractive, but not feasible. And even a complex rule is very unlikely to adequately capture the relevant contingencies, in part because many are impossible to predict ex ante.

This leads us to propose an alternative framework focused on enforceable fiscal standards rather than quantitative fiscal rules. By fiscal standards, we mean a statement of general objectives, coupled with a process for assessing whether member policies meet the standard, drawing on all relevant information. The present fiscal framework as laid out in Article 126 of the Treaty on the Functioning of the European Union (TFEU) actually starts with a standard: "Member States shall avoid excessive government deficits." But it then resorts to a system of quantitative fiscal rules to implement it, leading to the problems just described. We argue that, instead, stochastic debt sustainability analysis, undertaken at the EU level, is the main and right tool to define the concept of "excessive government deficits" and make it operational.

Our paper is organized as follows. Section 1 sets the stage. Section 2 discusses debt sustainability under the "pure public finance" view, i.e., ignoring the effects of fiscal policy on aggregate demand and the output gap. Section 3 extends the discussion to consider those effects, under the "functional finance" view of fiscal policy. In light of this analysis, section 4 presents and discusses the existing EU rules. Section 5 presents our proposal of fiscal standards. Section 6 concludes. 


\section{SETTING THE STAGE}

Historically, the need for EU-level fiscal rules in addition to national rules was justified by debt externalities across countries-adverse effects of unsustainable sovereign debt in one member country on other member countries, either through the spillovers of fiscal crises or through fiscal dominance of monetary policy, forcing the European Central Bank (ECB) to monetize and leading to inflation (Bini Smaghi, Padoa-Schioppa, and Papadia 1994; James 2012). In addition, there was clearly a suspicion, based on history, that some governments might have short horizons and might take more debt risk than justified, even from the viewpoint of their own country, with national fiscal rules either nonexistent or providing inadequate constraints.

Thus, in the transition and formation period of the euro, transparent and simple rules-such as the 60 percent debt-to-GDP ratio and 3 percent deficit limits-were seen as essential for credibility, and such simplicity may indeed have been justified at the start.

The rules were repeatedly violated, however, arguably because they were too stringent in some settings (e.g., forcing a country to consolidate in the middle of a recession), and not stringent enough in others (e.g., failing to sufficiently contain expenditure rises during the economic boom of the 2000s). A sense that the rules were both not sufficiently contingent and hard to enforce led to a series of modifications and steadily more complex rules. But the extended rules seem to have had perverse effects, constraining public investment and limiting the scope of fiscal support in the recovery from the global financial crisis. ' Enforcement has remained weak. Thus, even before the COVID-19 crisis, there was widespread agreement that the rules needed to be redesigned.

The COVID-19 crisis and forecasts of the post-COVID-19 environment have made the need for a redesign even more obvious. On the one hand, very large fiscal deficits have led to much higher levels of debt, far beyond the 60 percent target. On the other hand, interest rates, which had steadily declined since the mid-1980s, are expected to remain extremely low, indeed lower than GDP growth rates, for a long time to come. And, at the same time, limits on monetary policy arising from the effective lower bound have made fiscal policy a more essential macroeconomic tool.

All these make it urgent to deeply rethink the rules before they are put back in play.

\section{ASSESSING DEBT SUSTAINABILITY: THE PURE PUBLIC FINANCE VIEW}

The design of EU-level fiscal rules is a conceptually different issue from the design of national fiscal rules. Member countries should be free to pursue their preferred fiscal policy so long as their debt is sustainable. Some countries may, for example, want to favor future generations and aim for low or even negative public debt, while others may instead wish to maintain positive debt. Some countries may want to actively use fiscal policy to smooth cyclical fluctuations, while others may not. Member countries may or may not want to design their own fiscal frameworks (rules or standards) to help them reach these goals. These

On the procyclicality of rules, see for example Eyraud, Gaspar, and Poghosyan (2017) and

Claeys, Leandro, and Darvas (2016). On the effects of fiscal rules on public investment, see EFB (2019). 
choices should be left to individual countries. The purpose of EU fiscal rules or standards should only be to contain adverse debt-related externalities across members, by ensuring that each country's debt is indeed sustainable, and they should impose only the constraints needed for debt sustainability.

This section and the next explore how one should think about debt sustainability.

It is useful to start by ignoring the effects of fiscal policy on aggregate demand and in turn on output. ${ }^{2}$ Call this the pure public finance view. Is it a reasonable view? No. It would be if monetary policy and price adjustments could maintain output at potential, whatever the stance of fiscal policy. If there were a need for fiscal consolidation on public finance grounds, its effect on the output gap could then be offset by expansionary monetary policy and, if needed, an adjustment in relative prices. Fiscal policy could just concentrate on public finance issues. But price rigidities and potential constraints on monetary policy violate this assumption. However, it is still useful to start with it and relax it later.

Under the pure public finance view, when should one worry about debt sustainability and debt default? Many elements are in play from the level of interest rates and growth rates to the response of primary balances to debt to uncertainty about all of these, both now and in the future. The discussion is often confusing. What follows is an attempt at clarifying it, going down first a welltrodden and then a less traveled path.

\section{The Traditional Discussion}

The starting point of any discussion of debt sustainability is the basic equation for debt dynamics:

$b_{t}-b_{t-1}=\left(\frac{r-g}{1+g}\right) b_{t-1}-s$

where $b_{t}$ is the ratio of debt to GDP at the end of period $t, b_{\mathrm{t}-1}$ is its lagged value, $r$ is the interest rate on sovereign debt, $g$ is the GDP growth rate (with $r$ and $g$ either both nominal or both real), and $s$ is the ratio of the primary balance (defined as revenues minus expenditures excluding interest payments) to GDP, all in period $t$.

Solving the equation forward in time, this implies that the debt ratio in the future depends on the initial debt ratio, current and future interest and growth rates, and current and future primary balances. Governments have limited control over $r$ and $g$. The safe rate is under the control of the central bank, dependent on macroeconomic objectives. Potential growth is hard to affect, as structural reforms often have uncertain effects. Thus, the policy focus is on the primary balance, current and prospective, what it needs to be, and whether it can be achieved.

One then needs a definition of debt sustainability and, by implication, debt unsustainability. A working definition is that debt is sustainable so long as the probability of a debt explosion, and thus of eventual debt default, remains very low. The challenge is to determine the maximum level of debt that is sustainable.

2 This obviously does not exclude the possibility that fiscal policy, through the structure of taxation and spending, affects the composition of economic activity in many ways. 
It is useful to make a further simplifying assumption, that future interest rates and growth rates are constant and known with certainty. Once again, the assumption is clearly false. Interest rates and growth rates are both variable and uncertain, and the assumption will be relaxed below.

There are then two cases, depending on whether the interest rate is higher or lower than the growth rate, and the discussion depends very much on which case holds.

Assume first that the interest rate exceeds the growth rate, so $r-g>0$. This was indeed the case when the EU fiscal rules-also known as the Stability and Growth Pact (SGP)-were conceived in the 1990s.

If the debt ratio (debt for short in what follows) is to remain constant, we can solve for the steady state relation between debt and the primary balance ratio (primary balance for short):

$b=s\left(\frac{1+g}{r-g}\right)$, or equivalently $s=b\left(\frac{r-g}{1+g}\right)$

For any level of the primary balance $s$, there is a level of debt $b$ such that if debt exceeds $b$, debt will explode. Equivalently, for any debt level $b$, there is a level of the primary balance $s$ such that if the primary balance is lower than $s$, debt will explode.

This relation between debt and the primary balance, which depends very much on the value of $r-g$, is essential, but the equations do not tell us what debt level might be sustainable. For this, we need to know more about the behavior of the primary balance.

A reassuring theoretical and empirical answer was given in an influential paper by Henning Bohn (1998). So long as the primary balance reacts sufficiently to debt, any debt is sustainable. More formally, assume that the behavior of the primary balance is given by $s=s_{0}+a b_{\mathrm{t}-1}+$ cyclical component, with the average value of the cyclical component equal to zero. Then debt dynamics are given by

$b_{t}-b_{t-1}=\left(\frac{r-g}{1+g}-a\right) b_{t-1}-s_{0}-$ cyclical component

So long as $a>\frac{r-g}{1+g}$, the debt ratio will never explode but converge to a level that is positive if the average primary balance in the absence of debt, $s_{0}$, is negative; it will converge to a negative debt level otherwise-although if $\frac{r-g}{1+g}-a$ is small, this convergence will take a long time. Under the Bohn condition, there is no critical debt level, only a critical speed of adjustment of the primary balance to debt. Interestingly, Bohn found his condition to be satisfied in US historical data, with the parameter $a$ being around 5 percent annually, compared to 2-3 percent for $\frac{r-g}{1+g}$.

The Bohn conclusion is too optimistic, however, for one main reason. While an increase in debt may indeed lead, at least on average, to an increase in the primary balance, there are economic and political limits to how large a primary surplus a government can generate. When debt service requires a primary surplus that exceeds this limit, the Bohn condition no longer holds, and debt will explode.

Let $\bar{s}$ be the upper limit on the primary surplus a country can generate. The debt dynamics then imply that the highest sustainable debt ratio is given by $b^{*}=\bar{s}\left(\frac{1+g}{r-g}\right)$ 
Thus, if $\bar{s}$ is, say, 3 percent and $\frac{r-g}{1+g}=3 \%$, then the highest sustainable debt ratio is 100 percent. For any debt ratio above $b^{*}$, debt will explode relative to GDP.

The question is then: What determines $\bar{s}$ ? A useful way of thinking about it is as the sum of two components. The first is the current primary balance and the second is "fiscal effort" (i.e., the political will and room to raise the current primary balance if needed).

Take the first component. For a given fiscal effort by the government, the worse the current primary balance, the lower the maximum primary surplus that can be achieved.

Take the second component. The fiscal effort the government can make and sustain is clearly a function of many factors. It depends on the existing level of government revenues and thus on the scope to further increase taxes. It depends on the political system and the nature of a government: a coalition government may have a more difficult time increasing taxes or reducing spending. Fiscal effort also has a clear time dimension: one government may have the ability to increase the primary balance quickly, another more slowly; one government may be able to sustain a large effort for a long time, another not. This issue played a central role in the discussion of the sustainability of Greek debt in 2010: Could Greece really run a large primary surplus, as required in the adjustment program, not just for a few years but for more than a decade?

Historically, it is interesting to see what primary surpluses some EU countries have been able to achieve and sustain. For example, the 5-year average maximum cyclically adjusted surplus since 1980 has been 0.9 percent for France, 1.6 percent for Germany, and 1.5 percent for Italy. These may not be the right estimates of $\bar{s}$, however, as at least France and Germany were not under strong market pressure to adjust. Italy was, and, interestingly, looking not at the average level of the primary surplus but at its improvement over time, Italy was able to improve from a cyclically adjusted primary deficit of 3.4 percent in 1989 to a cyclically adjusted primary surplus of 6.5 percent in 1997, based on European Commission data (the surplus, however, fell to 0 percent by 2005).

\section{What Happens When $r-g<0$ ?}

The assumption that $r-g$ was positive and that countries with high debt had to maintain large primary surpluses very much underlay the construction of the EU rules, and is still the way many observers and policymakers think about debt sustainability. But the environment has steadily changed. Since the 1980 s, the neutral safe real rate (the rate required to maintain aggregate demand at potential output) has steadily declined. Even before the COVID-19 crisis, nominal interest rates on sovereign bonds were very low, even negative for some EU countries. The COVID-19 crisis has led to even lower nominal rates, and a flatter yield curve.

Figure 1 gives the yield curves for sovereign bonds for Germany, France, Spain, and Italy as of August 2020. German yields are negative up to almost 30 years, French yields negative up to 15 years, Spanish yields negative up to 7 years. Even for Italy, the country with the highest yields, the 10-year yield is 1 percent, the 30-year yield less than 2 percent. There are no growth forecasts that far out, but on the assumption of potential real growth equal to at least 1 percent and inflation equal to at least 1 percent (two extremely conservative assumptions), this implies negative values of $r-g$ for at least a decade, around 
Figure 1

Yield curves for Germany, France, Spain, and Italy as of August 2020

yield (percent)

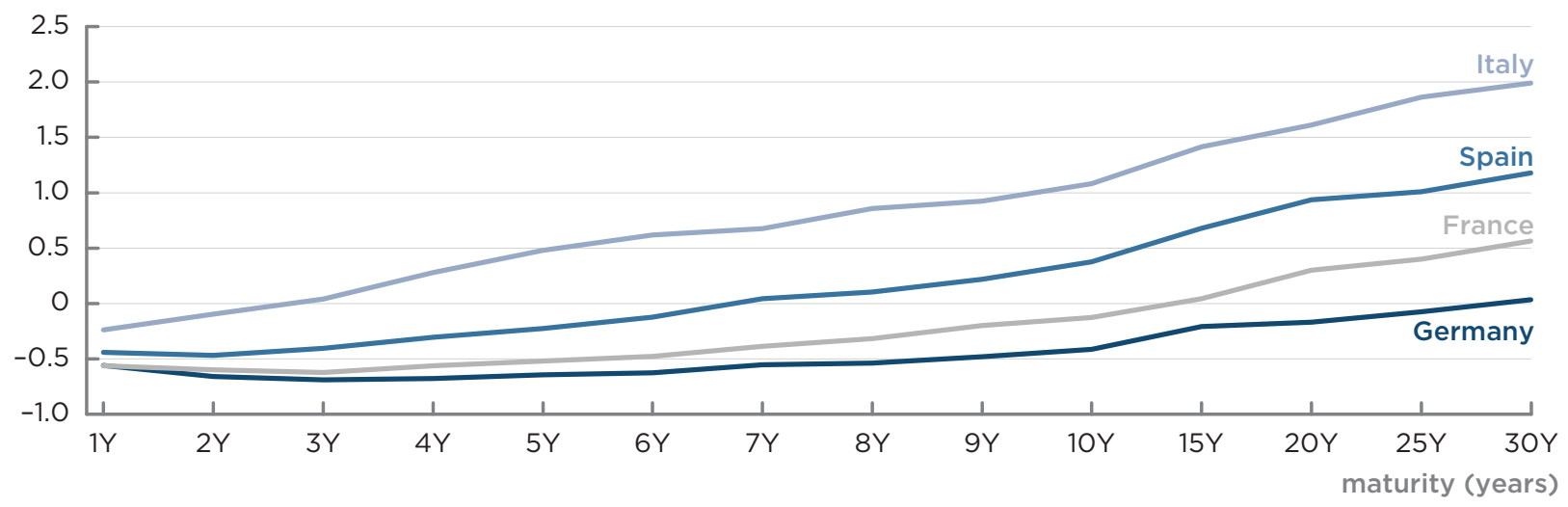

Source: Bloomberg.

-2 percent for Germany and France, closer to zero for Spain and Italy. (This still ignores uncertainty about these forecasts, which we return to below.)

When $r-g$ is negative, the dynamics of debt look very different. This can be expressed in various ways, all at odds with traditional wisdom but all following from the equation for debt dynamics above.

1 Whatever the primary balance, debt will not explode but converge to some finite value (so long as $s$ itself remains constant, i.e., does not increase year after year).

2 If the country maintains a primary surplus, debt will steadily decline and eventually converge to a negative number.

3 Maintaining a constant positive debt ratio does not require running primary surpluses but is consistent with running primary deficits forever.

For a numerical example, assume that $\frac{r-g}{1+g}=-2$ percent. Then, with a primary surplus of 1 percent, the debt ratio will eventually converge to -50 percentalthough, starting from the current EU average debt level of about 100 percent of GDP, it will take many decades to get there. If instead a government wants to stabilize debt at, say, 100 percent of GDP, it can still run a primary deficit of 2 percent of GDP. If it decides to run a primary deficit of 3 percent instead, the debt ratio will increase but stabilize at 150 percent.

This would seem to have a dramatic implication. No matter what the primary deficit, debt will not explode; put another way, debt sustainability is just not an issue. We are afraid that this is the lesson that some economists and some policymakers have drawn, but it goes too far, for two reasons. ${ }^{3}$ The first, discussed below, is the effect of public debt on the interest rate, even ignoring sovereign risk. The second has to do with sovereign risk and uncertainty more generally and is also discussed below.

3 The AEA address by one of the authors may have been partly responsible. It was, however, clear about the implications and the limits of the argument. See the corresponding AER article (Blanchard 2019). 
The fact that the interest rate is low despite high public debt should not be interpreted as indicating that debt has no effect on the rate but rather that other factors have been at play, more than offsetting the effect of debt on the interest rate (Rachel and Summers 2019). Leaving aside default risk, there are two channels through which a country's sovereign debt can affect its interest rate.

The first is the crowding out of capital, which increases the marginal product of capital, and by implication increases all interest rates, risky or safe, in some proportion. To the extent that national financial markets are integrated, however, the effect should depend not so much on the level of debt in any particular country but rather on the world's supply of sovereign bonds, or at least, in the case of the European Union, on the sum of EU member countries' debt rather than any particular national debt.

The second channel, separate from the crowding out of capital, is the increase in the supply of sovereign bonds of a particular country relative to the total supply of sovereign bonds. Even in the absence of default risk, sovereign bonds from different member countries are not perfect substitutes, because of either liquidity or price-risk differences.

How large are these effects likely to be for a typical EU or euro member? The truth is that economists have little sense of the right magnitudes. The econometric problem is that debt moves slowly, and many other factors affect rates. Theory suggests a wide range of answers, depending on the degree of departure from Ricardian equivalence. A general, although not solidly grounded, consensus is that, for a closed economy, a 1 percentage point increase in the debt ratio increases the interest rate (through the crowding out of capital) by 2 to 4 basis points. To the extent that the European Union is highly integrated, but still part of the world financial markets, this suggests a smaller coefficient for the effect of EU sovereign debt on the EU interest rate. Solid evidence on the second channel is nearly nonexistent but suggests some effect of own-country debt on own-country interest rate.

Suppose for the sake of argument that the effect is at the upper end of the range -4 basis points per 1 percentage point increase in the debt ratio-for a particular country. Then, starting from $r-g=-2$ percent, an increase of more than 50 percentage points in the debt ratio (e.g., from 100 percent to 150 percent) will shift the sign of $r-g$ from negative to positive and reintroduce the dynamics discussed earlier.

Put another way, assuming an upper bound for the primary surplus, we can derive an upper bound on the debt ratio, even if the current value of $r-g$ is negative. More specifically, assume that $r=r_{0}+c b$. Then, the debt limit is given by the solution to

$\frac{r_{0}+c b^{*}-g}{1+g} b^{*}-\bar{s}=0$

Choose $c$ to be 0.04-almost surely a generous upper bound on the effect of own-country debt on the interest rate. Assume $r=0$ percent, at the current debt ratio of roughly 100 percent, so by implication $r_{0}=-4$ percent. Assume $g=2$ percent and $\bar{s}=-2$ percent. Then the solution to the quadratic equation $(-0.06+$ $\left.0.04 b^{*}\right) b^{*}-0.02=0$ gives a debt limit of 178 percent. Choose $c$ to be a more realistic 0.02 and go through the same steps, and the solution becomes 241 percent. 
Thus even if the interest rate is less than the growth rate today, a large increase in debt might change the sign of the inequality and lead again to a debt limit. For plausible values of the effect of the debt ratio on the interest rate, the debt ratios beyond which debt explodes are finite, but fairly high.

\section{Uncertainty}

So far, the discussion has assumed that future values of $\bar{s}, r$, and $g$ were known with certainty. This is clearly not the case and this, not surprisingly, has major implications. One of them is to generate a second reason for being careful about high and rising debt even when $r-g<0$.

That debt forecasts and thus debt sustainability assessments are made under substantial uncertainty is obvious. This includes uncertainty about future $s$ (arising from uncertainty about the size of future off-budget liabilities, i.e., having to finance the retirement system out of the budget makes it harder to achieve any primary balance target), about economic shocks, about future interest rates, and, to a lesser extent (in terms of range), about future growth rates. And it also includes uncertainty about the size of the feasible fiscal effort (the ability of the government to increase taxes or spending if needed), which determines $\bar{s}$ given $s$.

As the various formulas above have shown, for a given $\bar{s}$ any debt limit is extremely dependent on $r-g$ (which always appears in the denominator). In the previous example suppose that future $r$ turns out to be higher by 2 percent than it is today, so $r-g$ becomes equal to 0 . Then, the same computation implies that the debt limit goes down from 241 percent to 162 percent. Put another way, the adjustment in the required primary balance for a given level of debt must equal 2 percent times the level of debt, 4 percent of GDP if the debt ratio was, say, 200 percent to start, and this new level of the primary balance has to be sustained over time. This may well be politically infeasible.

In the current context, the main question is over the probability of moving from a regime where $r-g$ is negative to one in which it is positive and perhaps large. In the past, periods of negative $r-g$ have alternated with periods of positive $r-g$ (Blanchard 2019).

One can get a sense of what investors in financial markets believe by looking at the probabilities implicit in the option prices on bonds of different maturities. As of August 2020, the implicit probability that investors put on the euro 3-month Libor rate exceeding 3 percent in 5 years was just 1 percent, and the probability that they put on it exceeding 3 percent in 10 years was only 7 percent. There are no corresponding available probabilities for growth forecasts, but it seems safe to assume that the probability that nominal GDP growth over such a long horizon will be less than 3 percent is small. Furthermore, if the interest rate were to increase substantially, it would probably be partly because of good news on potential growth, so that the difference between the two might well remain negative even then. This implies a high probability, at least based on market forecasts, that $r-g$ will remain negative for at least a decade.

Furthermore, how much interest rate uncertainty matters for the evolution of debt depends very much on another factor, the maturity of the public debt. The longer the maturity, the more the state can protect the evolution of debt from movements in short-term interest rates, in this case from potential sharp increases in the future. In the case of the European Union, most governments 
have substantially increased the maturity of their debt over time: The average maturity of debt is 8 years in France and Germany, and 7.3 years in Spain and Italy (in the case of Italy, up from 2.5 years in the early 1990s). This considerably reduces the risk of a large sudden increase in interest payments over the coming decade.

Interest rate risk is far from the only risk. As the COVID-19 crisis has shown, adverse shocks can lead to very large deficits and increases in debt. In most countries, current forecasts are for debt ratios to be at least 10 percent to 20 percent higher than was forecast before the crisis (some debt ratios have already increased more than this, but this is in part because of the large decrease in output in 2020, which is partly temporary), and another series of lockdowns could easily lead to much larger numbers. Conceivably, it may lead to a debt explosion, a scenario in which achieving $\bar{s}$ might not be enough to prevent a steady increase in debt-and eventual debt default.

This leads to an important remark: Almost no debt ratio is absolutely safe. What governments or the European Union should aim for cannot be absolute debt sustainability, but debt sustainability with high (very high?) probability. And this leads to the next point: The probability of debt default affects the debt dynamics, and even a small probability of default quickly leads to much worse debt dynamics. Other things equal, a probability of default of 2 percent will increase the required rate on debt by 2 percent, leading to the need for a much larger primary surplus to stabilize debt.

Ignoring the effect of the probability of debt sustainability on the interest rate, we computed above a debt limit of 162 percent of GDP. It is clear that if the debt ratio were to come anywhere close to that number, investors would start worrying about shocks taking debt over that limit, leading to debt default. Thus, they would price in this probability and require a risk premium, and the higher interest rate in turn would make it likely that debt exceeded the limit, leading to default. In other words, under uncertainty, the debt limit (the debt level at which debt was sustainable with high probability) would be much lower than 162 percent.

How much lower? The answer is again that it is hard to tell, for two reasons (here, again, some of the discussion is familiar territory, some less so; a recent analysis is given in Lorenzoni and Werning 2019).

The first is that the interaction between the probability of default and the evolution of the debt is likely to lead, at a given debt level, to multiple equilibria: a "good equilibrium," where investors assume a low probability of default, the interest rate remains low, and debt is sustainable with the correspondingly high probability; and a "bad equilibrium," where investors assume a high probability and require a high rate, which in turn leads to the correspondingly high probability of default. The range of debt ratios for which the two equilibria coexist can be very large, depending in particular on the size of the haircut in case of default. Importantly, in plausible simulations, multiple equilibria can happen at very low levels of debt, much lower than the current levels.

This problem can, however, be eliminated if the central bank is willing and able to eliminate the bad equilibrium by committing to maintain the good equilibrium by buying bonds at the lower interest rate. Central banks have shown a willingness to do so, from the Bank of Japan committing to an explicit rate on long maturity bonds to the ECB committing to "market stabilization." Whether 
this is a foolproof way of eliminating the bad equilibrium may be tested in the future. Investors may decide that the purchase of sovereign bonds by the central bank is simply a transfer of liabilities from the state to the central bank and does not change their consolidated liabilities vis-à-vis the public. This might lead such an intervention to fail. In the case of the euro area, however, the purchase of one country's sovereign bonds by the ECB decreases that country's liability and increases the liabilities of all the other euro members; to the extent that other members are in a more solid position, this makes the intervention more likely to succeed.

The second reason is that even in the "good equilibrium," the level of debt consistent with sustainability with high probability may be low. The intuition is as follows. Ignore the effect of the probability of debt sustainability on the interest rate and start from a debt level that is clearly unsustainable even under this assumption. This gives a first debt limit. Then iterate backward in time. As debt gets close to this debt limit, investors will put a high probability on shocks leading debt to exceed that limit, leading in turn to a high interest rate and thus a lower debt limit. If, however, debt gets close to this now lower limit, investors will again worry about debt exceeding that limit, leading again to a high interest rate, a lower debt limit, and so on. Depending exactly on how expectations are formed-how foresighted investors may be, the credibility of the government in limiting debt increases-the maximum debt ratio at which the probability of default starts being positive may be very low even in the "good equilibrium," lower than existing debt ratios. ${ }^{4}$

The story is further complicated when we consider the fact that fiscal policy affects aggregate demand, the so-called functional finance view.

\section{IMPLICATIONS OF THE FUNCTIONAL FINANCE VIEW}

The pure public finance view ignores the role of fiscal policy as a macroeconomic stabilization tool. This is clearly not right. Because of nominal rigidities, domestic fiscal policy typically affects domestic demand and domestic output. This points to what Abba Lerner (1943) called the functional finance role of fiscal policy.

For our purposes, this has two implications, which would hold even if a country were not in a common currency area:

- The need to use fiscal policy as a macroeconomic tool, in particular the need to run larger deficits when there are adverse macroeconomic shocks. The more limited the scope for monetary policy, as is the case now and for the foreseeable future, the stronger this need.

- The need to run such deficits without threatening debt sustainability. A more aggressive fiscal policy implies larger variations in the primary balance, and thus, other things equal, the need for a lower level of debt in normal times, to have the room to run deficits without substantially increasing the risk of debt default when shocks occur.

4 The last two paragraphs are based on current research by one of the authors (Blanchard). This research, joint with Michael Kister and Gonzalo Huertas, focuses on the evolution of debt when the interest rate charged by investors depends on the risk of default, and, in turn, the evolution of the debt and the risk of default depend on the interest rates. Preliminary findings suggest that the increase in the probability of default can be very sudden, and that there is a substantial range of debt levels where there is both a good and a bad equilibrium. 
A consequence of these facts is that large adverse shocks can create a conflict between the macroeconomic stabilization function of fiscal policy and the objective of maintaining debt sustainability with high probability. It would probably have been taboo to state this until the COVID-19 crisis, but the crisis has clearly made the point. Nearly all economists agree with the priority given to the spending and revenue measures taken by governments and the associated very large deficits. There was and still is wide support to invoke escape clauses in the SGP to suspend EU fiscal rules. It is clear, however, that the risk of eventual debt default, whether through straight default or by inflating some of the debt away in the future, has increased, if ever so slightly. In other words, faced with the need to protect households and firms and boost demand, governments have been willing to accept a large increase in debt, which involves some risk.

One additional implication of the functional finance view is specific to countries in a common currency area such as the euro area, namely, the relevance of a second type of cross-county externalities associated with fiscal policy: demand externalities (in addition to debt externalities).

For any pair of economically integrated countries, regardless of whether they share a currency, fiscal policy can have spillovers in the sense that a fiscal expansion or contraction in one country may affect not only domestic output but also output in the other country. When the two countries are not members of a currency union, they have the option of using monetary policy to offset fiscal spillovers. This option is not available to countries within the euro area. Given the high degree of goods market integration, this may lead each country to underuse fiscal policy. A fiscal expansion in Luxembourg has a limited effect on the demand for Luxembourg's goods, with much of the increase in demand falling on Belgian, French, and German goods. It is therefore more likely to lead to a worsening of Luxembourg's current account balance than to an increase in the country's output, making it unattractive for Luxembourg to use as a macro tool. More generally, this may lead fiscal policy to be underused relative to what would be optimal for the euro area.

When monetary policy can be used, an insufficient EU-wide fiscal policy response can be offset by more expansionary monetary policy, maintaining euro area output at potential. This becomes much more difficult when, as is the case today and likely to be the case for some time, the ECB and most of the other central banks of the European Union operate at the effective lower bound on interest rates. In this case, in the presence of a common adverse shock, the optimal fiscal policy for the European Union as a whole is for each country to do more than it would want to do on its own, or for the countries to agree to produce the necessary fiscal stimulus through a common budget expansion at the EU level. The second option seems politically more feasible, and one can see the creation of the recovery fund as a step in that direction. Absent that option, the limits on further expansionary monetary policy suggest yet another element that should be considered in thinking about output stabilization versus debt sustainability, namely, demand externalities.

Putting this and the previous section together, we propose five conclusions about assessing and enforcing debt sustainability in the context of the European Union. 
The first conclusion, which will be obvious to the reader of the last two sections, is that this is a complex issue, that there is no single, time-countryinvariant, magic debt or deficit number.

The second conclusion is that debt sustainability is fundamentally a probabilistic statement. This follows naturally from the notion that most of the relevant variables have distributions with unbounded supports. This is recognized, for example, in the IMF's "three zone" approach to debt sustainability: The IMF distinguishes between debt that is considered unsustainable, debt that is sustainable but not with high probability, and debt that is sustainable with high probability.

The third conclusion is that the way to think about sustainability is to focus not just on debt but also on the primary balance. High debt is not an issue if the primary balance that is needed to sustain it, now and in the future, is well within the ability of the country to achieve.

The fourth conclusion is that, for a given level of debt, the primary balance the country needs to achieve depends very much on the difference between the interest rate and the growth rate, both now and in the future. Thus, both the first and the second moments of these two variables matter. While, for the time being, the difference is negative and implies that even high debt is consistent with a primary deficit, the probability that the sign may change must be taken into account in thinking about the evolution of debt and debt sustainability.

The fifth conclusion is that the primary balance that a country can achieve also depends on many factors. For example, it depends on both the current primary balance and its future evolution: Other things equal, the worse the current or future primary balance, the more difficult it is to achieve and sustain the primary balance required for debt sustainability. Here again, first and second moments matter very much: Even a primary surplus can become a large deficit if the economy is affected by adverse shocks, from regular macro shocks to financial crisis shocks such as the global financial crisis or health shocks such as the COVID-19 crisis. Other things are not equal, however, and the ability to improve the primary balance also depends on many country- and time-specific factors, from the starting level of taxes to the type of government, its commitment, and its ability to improve the primary balance and sustain it if needed.

An assessment of debt sustainability must thus take all these factors into account, including the uncertainty associated with each one. We now turn to an examination of the EU fiscal rules and assess them in light of this discussion.

\section{THE EU FISCAL RULES}

We begin with a brief description of the current architecture. The history of the EU rules is one of "sedimentation over time" (Deroose et al. 2018). The Maastricht Treaty (1992) and the Stability and Growth Pact (1997) established the basic architecture, articulated around two reference values: 60 percent for the gross debt-to-GDP ratio and 3 percent for the overall budget deficit. The simplicity and uniformity of the rules were seen as essential to credibility, although some flexibility and country-specific characteristics could be reflected through the enforcement process, which allowed for political compromises (Bini Smaghi, Padoa-Schioppa, and Papadia 1994). 


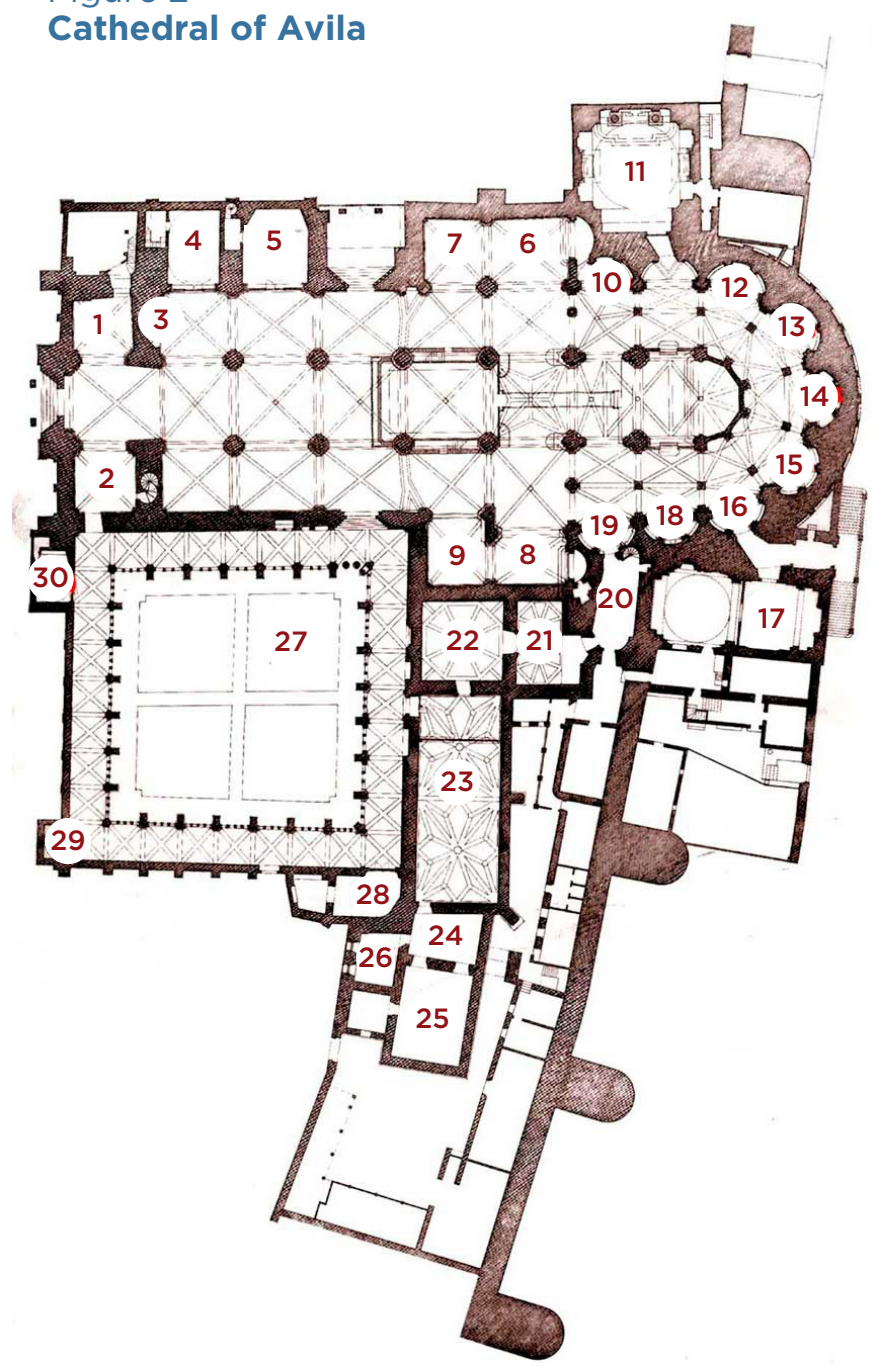

1. Capilla de san Miguel

2. Capilla de san Andrés

3. Pila bautismal

4. Capilla de la Piedad

5. Capilla de la Concepción

6. Capilla de san Antolín

7. Capilla de san Pedro

8. Capilla de santa Teresa

9. Capilla de san Ildefonso

10. Capilla de san Rafael

11. Capilla del Sagrado Corazón

12. Capilla de san Nicolás

13. Capilla de Santiago

14. Capilla de Na Sa de Gracia

15. Capilla de san Juan Evangelista

16. Capilla de san Esteban

17. Capilla de san Segundo

18. Capilla de la Asunción

19. Capilla de san Juan Bautista. Acceso a las dependencias del Cabildo

20. Sacristía románica

21. Capilla del Sagrario / Antesacristía

22. Capilla de san Bernabé / Sacristía

23. Librería / Capilla Quiroga

24. Atrio del Capítulo nuevo / Sala de los Cantorales

25. Sala capitular nueva

26. Antiguo archivo catedralicio / Sala de la Pasión

27. Claustro

28. Capilla de las Cuevas

29. Capilla de Na Sa de la Claustra

30. Capilla del Crucifijo

Source: https://www.lacatedraldesevilla.org/en/cathedral-parts.html.

The rules quickly proved too stringent, leading to widespread violations, and were modified in a series of reforms, in 2005, 2011, 2013, and 2015. Each reform allowed more differentiation, more contingencies to reflect macro realities. The result, however, is extraordinarily complex, and often feels like the Cathedral of Avila: The original structure is still recognizable, but the many additions make it hard to see the consistency of the whole. (See figure 2).

That said, the EU rules are still anchored around the two initial numbers, with the 60 percent number for debt remaining the ultimate objective. To achieve it, countries face two sets of constraints: on their structural balance and on their expenditure growth.

5 A short history is given in https://ec.europa.eu/info/business-economy-euro/economicand-fiscal-policy-coordination/eu-economic-governance-monitoring-prevention-correction/ stability-and-growth-pact/history-stability-and-growth-pact_en. A detailed description of the current rules is given by the European Commission (2019). 


\section{The Medium-Run Target for the Structural Balance}

The structural balance is defined as the overall budget balance, cyclically adjusted for the estimated output gap, using a country-specific elasticity of revenues and expenditures to the output gap. It is also net of one-off expenditures and revenues. Finally, it includes (nominal) interest payments and is thus different from the primary balance.

The first set of rules aims at making sure that the structural balance does not exceed a medium-term objective (MTO), which is itself the maximum of three different limits:

- Whatever structural balance is needed to ensure that, even for a large negative output gap (based on historical country-specific evidence), the overall deficit will not exceed 3 percent.

- For countries whose debt ratio exceeds 60 percent, the structural balance that ensures a declining debt ratio over time, taking into account the effects on the deficit of increasing costs due to aging. The formula implies that, for example, for a country with a debt ratio of 110 percent, the structural balance must exceed the debt stabilizing value by 1.4 percent of GDP.

- A structural balance of at least -1 percent or, for countries with debt higher than 60 percent, at least -0.5 percent (this applies to euro area and ERM II members).

Which limit turns out to be the maximum of the three varies across members. In 2019, twelve EU countries, including France and Germany, had an MTO for 2020-22 of 1 percent. Some countries had a tighter limit: for example, Spain and Belgium had an MTO of O percent; some had a looser limit: for example, Hungary had an MTO of 1.5 percent and Croatia an MTO of 1.75 percent. (The requirement to adjust toward MTOs was suspended when escape clauses were invoked.)

\section{The Expenditure Rule}

The second set of rules requires that the growth of expenditure-net of cyclical unemployment benefits, interest payments, and new taxation, and with smoothing of investment expenditures-be the same as the potential growth rate of output. If the structural balance is worse than the MTO, then the growth of expenditure must be reduced, according to a formula.

If one thinks of the elasticity of taxes to potential growth as roughly equal to 1 , this can be thought of as requiring that expenditure and revenues grow at the same rate as output, and thus as requiring a constant cyclically adjusted primary balance ratio.

Why the use of a second set of rules? Because of worries about the measure of the output gap in the computation of the structural balance. The expenditure rule does not require a measure of the output gap but rather of the potential growth rate. Neither the output gap nor potential growth are perfectly measured, and thus it was determined that using both would be better than using one.

If countries do not satisfy these two rules they can be, by decision of the Council, subject to a Significant Deviation Procedure, which can eventually lead to sanctions in the form of an interest-bearing deposit of 0.2 percent of GDP. 


\section{A Corrective Process}

If countries breach either of the two reference values (if the deficit is above 3 percent or the debt is above 60 percent and the gap is not falling by $1 / 20$ per year), they can be, again by decision of the Council, subject to the "corrective" rather than the "preventive arm," also called the Excessive Deficit Procedure (EDP). They then must correct the excessive deficit or excessive debt in a "timely manner." In the case of a breach of the 3 percent deficit, this should be corrected within one or two years. For debt, the deadline may be longer depending on the circumstances (so far, no country has been subject to EDP for breach of the debt criterion). The Commission has flexibility to set the requirements for adjustment. If there is still insufficient adjustment, then the Council can impose a fine of a maximum 0.2 percent of GDP per year.

\section{Flexibility Clauses}

The reforms have introduced several flexibility clauses. In particular, the required fiscal adjustment when the structural balance is short of the MTO can be reduced or even suspended if economic conditions are bad. In "exceptionally bad times," defined as a negative output gap of more than 4 percent or negative real growth, no adjustment is required. Yet, note that even in this extreme case, there is no allowance for a temporary reversal. When deciding whether to launch an EDP, the Council has substantial leeway to find special circumstances or accept a temporary breach, for example. And, obviously, the rules can be suspended, as has been the case since March 2020.

\section{Assessing EU Rules}

The discussions of debt sustainability in the two earlier sections and of actual rules in this section feel very different. The first emphasized the complexity of determining the right debt limit and how it was likely to be highly country and time specific. The second shows that the EU rules are still fundamentally based on an invariant debt target, with some flexibility in the adjustment process.

The extensions that were added through various reforms often seem like a series of repairs rather than a coherent set of rules. Take the measure of the deficit. Does it really make sense to have the overall fiscal balance (uncorrected for the inflation component of interest payments) in the MTO, and something close to the primary balance in the expenditure rule?

Going beyond the general architecture, it is useful to compare the rules to some of the conclusions of the previous two sections:

Take first the adjustment with respect to $r-g$. A recurring theme of the previous sections was that the appropriate debt limit depends on both first and second moments of the distribution of $r-g$. Yet the EU rules are still based on an invariant debt target of 60 percent of GDP. (Given the evolution of debt during the COVID-19 crisis and the fact that many countries are likely to have debt ratios in excess of 100 percent, keeping this target will likely be awkward.) The rules allow movements in $r-g$ to have a minor effect on the speed of adjustment to the debt target, as a reduction in interest payments together with an unchanged MTO allows for a lower primary balance. But if the expenditure rule is binding, then there is no flexibility in adjusting the primary balance. 
Consider the adjustment with respect to output fluctuations. MTO targets are unaffected. The structural balance is adjusted for cyclical fluctuations, so the distance between the structural balance and the MTO is in principle invariant to cyclical fluctuations. Put another way, the rule allows for automatic stabilizers to function. The speed of adjustment of the structural balance to the MTO is also allowed to depend on the output gap. But, as discussed earlier, the most the rules allow for is a suspension of the required adjustment if the output gap is large and negative or if growth is negative, never a reversal. There is no accommodation of the case where the ECB is at the effective lower bound and fiscal policy becomes the main macroeconomic tool.

\section{A REFORM PROPOSAL: FISCAL STANDARDS}

The case for a deep reform of the EU fiscal rules is not controversial. Before COVID-19, the rules were widely seen as too complex, procyclical, and hard to enforce. With COVID-19 and much higher levels of debt, it is clear that the adjustment that would be required under the rules would lead to too sharp a fiscal contraction in an environment in which the ECB would have limited room to help.

The question is how to reform.

One reaction to the analysis presented in preceding sections is that this is fine as an academic discussion, but much too complex to be implemented; that we have little clue about the right debt levels except to say that higher debt levels are more dangerous than lower debt levels; that modifying or abolishing the 60 percent and 3 percent debt and deficit benchmarks would require Treaty change. Hence, keeping these benchmarks while simplifying the rules and making them less procyclical is the realistic way to proceed.

Most recent proposals are in that mode. The 60 percent debt ratio is retained as a long-term debt anchor for higher-debt countries and as a dividing line between the fiscal rules that apply for countries with debts above and below. At the same time, most proposals argue for replacing the plethora of existing rules and procedures-the medium-term objective, the expenditure rule, flexibility clauses, the Significant Deviation Procedure, the Excessive Deficit Procedurewith just one operational rule: an expenditure rule that implies a trend decline in debt while allowing fluctuations in the deficit driven by cyclical changes in revenue. ${ }^{6}$ Some proposals also present ideas on how to improve enforcement. ${ }^{7}$

6 Claeys, Leandro, and Darvas (2016), Beetsma et al. (2018), Bénassy-Quéré et al. (2018), Darvas, Martin, and Ragot (2018), Feld et al. (2018), EFB (2019), and Constâncio (2020) all propose replacing the rules with an expenditure rule and a debt anchor (in most cases unchanged at 60 percent of GDP). Some proposals envisage an "adjustment account" to capture limited deviations from the rules, which can be drawn or paid down in subsequent years. Feld et al. (2018) propose keeping the structural balance rule as an additional operational rule, with deviations again captured in an adjustment account. Bénassy-Quéré et al. (2018) suggest that the debt anchor could be country-specific to capture national implicit liabilities such as those arising from the public pension system. Andrle et al. (2015) and Gaspar (2020) consider alternative operational rules (expenditure rule, revenue rule, balanced budget rule) tied to the debt anchor.

7 These include making enforcement and sanctions more automatic and less political, a higher involvement of national fiscal councils, the introduction of positive conditionality (such as allowing preferred access to a possible stabilization function or ESM loans), and, in BénassyQuéré et al. (2018), that countries should issue junior sovereign bonds to fund spending above the expenditure rule ceiling. 
While an improvement, rules of this type are still going to lead to costly mistakes. They could be too tight: While they would allow fiscal stabilizers to take effect, they would not allow discretionary stimulus beyond the prescribed maximum expenditure growth rate. In a major, protracted downturn, they would be far too constraining. They could also be too loose: While they are designed to keep a lid on procyclical increases in expenditure, they do not prescribe particularly urgent adjustment for countries that are near their debt limits, which are likely country-specific and change over time in line with changes to expected growth and long-term interest rates.

Addressing this problem would require building additional contingencies into the rules. One easy contingency could be a general escape clause of the type that exists in the present rules and was invoked for COVID-19. Most proposals would maintain such an escape clause. However, it could be used only in the case of large, aggregate shocks that affect the entire European Union-and when it is invoked, it simply temporarily suspends the rules, leaving nothing in their place. Bringing the rules closer to the optimal trade-off between allowing stabilization policy and limiting the risk of unsustainable debt for each EU member requires a vastly more complex set of contingencies. But this would make the rules even more complex and state-contingent than the current rules-the opposite of what most recent proposals are trying to achieve.

The most important argument against fiscal rules, however, is not that getting the trade-offs right would require even more complexity. Rather, it is that economists would be incapable of defining any rule that gets the tradeoffs right ex ante, even when given a free hand in making the rules as complex as desired. The reason for this is "Knightian uncertainty": many relevant contingences, the probabilities associated with them, and the right way to map them into a rule are impossible to identify ex ante. Section 3 showed that the highest sustainable debt ratio depends on parameters of the economy and the political system that are intrinsically uncertain and interact with each other in complex ways. To account for these uncertainties, a rule that seeks to map observable economic variables into a maximum "safe" debt level would have to take an exceedingly conservative approach. While "conservative" may sound good, it implies that in most states of the world, such a rule would be excessively restrictive in constraining fiscal policy in its stabilization function. Conversely, a rule that is calibrated to allow adequate space for stabilization policy would have to give countries so much free rein to create debt that they could easily end up in the danger zone. One way or the other, rules that attempt to codify the trade-off between debt risks and stabilization benefits of fiscal policy ex ante will get it wrong. ${ }^{8}$

The only way to escape this dilemma is to move away from fiscal rules. This requires an alternative approach that allows the European Union to meaningfully constrain the fiscal policies of its member states when needed: one that looks at each case individually, taking into account country and context specificities, and comes to a judgment on whether fiscal policy needs to be adjusted. Rather than

8 See Wyplosz (2005), Hatchondo, Martinez, and Roch (2012), and Odendahl (2015) for related descriptions of the problem (but differing solutions). 
attempting to codify the trade-off between debt risks and output stabilization ex ante, this trade-off would be evaluated continuously, based on all information available at the time.

Fortunately, such an approach exists: the legal literature refers to it as a standard, as opposed to a rule. In the supranational context of the European Union, it would not be easy to implement. But unlike fiscal rules, it stands a chance conceptually.

\section{Standards versus Rules}

Rules and standards are alternative ways of writing down legal norms that regulate behavior. ${ }^{9}$ The difference between them is in the degree to which legal content is defined ex post, at the point of application, rather than ex ante. The limit case of a rule is a legal norm in which all legal content is defined ex ante, such as "do not drive faster than 55 miles an hour." The limit case for a standard is a norm in which all legal content is defined ex post, such as "do not drive at excessive speed." What "excessive speed" means exactly is left to the driver (and in the event of a dispute, to a court), based on social norms and legal precedent.

Most legal norms lie between these extreme cases. Standards may list criteria that adjudicators must consider when deciding whether the standard was met, making them more rule-like. Rules may include exceptions or state contingencies, as is the case for today's EU fiscal rules, moving them closer to standards.

Both standards and rules are commonplace in national and EU law. In the present EU fiscal framework, paragraph 1 of Article 126 of the TFEU, "Member States shall avoid excessive government deficits," constitutes a pure standard, while the requirement that countries with a structural balance below -0.5 percent of GDP must increase it by at least 0.5 percentage point of GDP every year (see section 4) constitutes a pure rule. Large swaths of EU law, such as competition law, are based on standards. ${ }^{10}$ In contrast, legal frameworks that seek to constrain fiscal policy tend to be based on rules, but with exceptions.

An important such exception is New Zealand's fiscal framework, initially laid out in its Fiscal Responsibility Act of 1994, which is written entirely in terms of standards (referred to as "principles of responsible fiscal management"; New Zealand Treasury 2015 and 2019). These standards describe both pure and functional public finance objectives, including: "Achieve and maintain prudent public debt levels"; "Ensure that, on average, Crown operating expenses do not exceed Crown operating revenues"; "Achieve and maintain levels of Crown net worth to provide a buffer against shocks"; "Manage fiscal risks facing the Crown prudently; "Consider the likely impact of fiscal strategy on present and future generations"; and "Have regard to the interaction between fiscal policy and

9 The legal literature on the subject is extensive, and includes contributions by Sunstein (1995), Kaplow (1992), Schlag (1985), Ehrlich and Posner (1974), Hart (1961, 2013), and Pound (1922). We thank Yair Listokin, Anna Gelpern, and Leland Smith for introducing us to this literature and providing us with references.

10 The EU Guidelines on the Assessment of Horizontal Mergers, for example, lay out how the Commission performs an overall competitive appraisal of mergers and which factors it will take into account when assessing whether these mergers are harmful to the European consumer. Considerations include the degree of possible efficiency gains from mergers versus their potential harm to consumers, their verifiability, and whether they are expected to occur in a timely manner and ultimately benefit the consumer. 
monetary policy" (New Zealand Treasury 2015, 5). According to the New Zealand Treasury $(2015,3)$, the adoption of fiscal rules was periodically considered but rejected because, among other reasons, "a legislated fiscal rule will not necessarily reflect the government of the day's assessment of what constitutes good fiscal policy" and "a transparency-based framework will usually be more flexible than a legislated fiscal rule. For example, a limit on Crown borrowing could require a government to cut spending even if the evidence suggests that doing so would have negative consequences for economic growth or living standards more generally."11

Depending on the circumstances, rules may be preferable to standards and vice versa. Rules have the advantage of providing greater clarity ex ante. But a case-by-case approach guided by standards may be preferable when "public authorities cannot design general rules, because they lack relevant information...or rules [would] be poorly suited to new circumstances turned up by unanticipated developments" (Sunstein 1995, 957). ${ }^{12}$ For the reasons explained above, we believe that this applies to EU fiscal rules today.

\section{Implementing Fiscal Standards}

The crux of implementing a fiscal standard is of course how to recognize "excessive" (or conversely, "prudent") debt and deficit levels. In the absence of a long body of case law (or universally accepted definitions of these terms), these terms would need to be defined and the definitions elaborated in EU law. For this reason, we are not arguing for replacing EU fiscal rules by a pure standard-as would be the case if, for example, the fiscal framework were reduced to Article 126, paragraph 1. Rather, we argue for fiscal standards accompanied by criteria, procedures, and methods that describe how to apply them. These could be codified at several levels of EU legislation.

At the highest level, the current EU fiscal standard, "Member states shall avoid excessive government deficits" (Article 126 TFEU), could be maintained. Below that level, EU secondary legislation could determine that deficits are to be considered excessive when debt does not appear to be sustainable with high probability, conditional on current and projected policies. It could also state that when this is the case and an adjustment is needed, deficits should be reduced in a way that balances the risks to debt sustainability with the output costs of adjustment (for the member in question and potentially other members). Alternatively, Article 126 TFEU could be amended to make the general fiscal standard(s) more precise-requiring members to ensure that public debt

11 While the New Zealand government has in the past interpreted "prudent public debt levels" in terms of quantitative ranges (for example, the December 2019 Budget Policy Statement stated that "Prudent levels of net core Crown debt are within a range of 15 to 25 per cent of GDP (subject to any significant shocks to the economy)"), these were never legislated. Furthermore, quantitative debt targets were abandoned after the COVID-19 shock. The government's latest Fiscal Strategy states that "The Government will stabilise and then reduce net core Crown debt to prudent levels over the long term (subject to any significant shocks) and beyond. Prudent levels of net core Crown debt are those that are within sustainable limits and provide a buffer for future shocks" (New Zealand Government 2020, 42).

12 See also Hart (1961, 126-35), Schlag (1985), and Kaplow (1992). 


\section{Box 1 What EU fiscal standards might look like: Examples}

I. General fiscal standards-embedded in EU primary legislation (e.g., Article 126 TFEU)

1. "Member states shall ensure that their public debts remain sustainable with high probability"

2. ["When there is doubt as to whether public debts remain sustainable with high probability, members shall reduce their primary deficits at a speed that balances risks to sustainability and short-term risks to output"]

II. Criteria and procedures to decide whether the standards are met-EU primary or secondary legislation (regulations or directives), national laws consistent with secondary legislation

1. Criteria establishing whether debt is sustainable with high probability: use of a debt sustainability framework developed by the European Commission and/ or the European Fiscal Board that delivers probabilistic assessments and is periodically revised and validated externally

2. Criteria establishing risks to sustainability: use of the same framework

3. Criteria establishing risks to output: consider the state of the economic cycle, market conditions, and whether the ECB is constrained by the effective lower bound on interest rates

4. A procedure that assigns responsibility for an initial determination of whether the standards are met, to either an EU-level institution (e.g., the European Commission, the European Fiscal Board) or a national independent fiscal institution

III. Methods to determine whether criteria are satisfied-European Commission documents and/or commonly agreed positions of the EU Economic and Financial Committee

- A framework for stochastic debt sustainability analysis,

- A method (or multiple methods) for deciding on the state of the economic cycle, and

- A method (or multiple methods) to assess whether the ECB is constrained by the effective lower bound.

remains sustainable with high probability-and possibly to lay out a standard to determine the appropriate speed of adjustment if debt sustainability is at risk.

Box 1 provides some examples.

The primary tool for assessing whether the fiscal standard is satisfied would be stochastic debt sustainability analysis. Conceptually, this analysis would generate a distribution of paths of the debt ratio (sometimes called a "fan chart"), based on forecasts for the drivers of the debt dynamics, which are themselves stochastic: the path of primary balances, one-off liabilities (e.g., related to aging or the retirement system), growth, interest rates, and the maturity structure of the debt. The forecasts would also take into account the policy intentions of the authorities as well as the interactions between growth and fiscal policies. The result would be a distribution for the debt ratio $n$ years 
out, for the actual primary balance, and for the debt-stabilizing primary balance, conditional on expected policies (but allowing for uncertainty about how these policies would affect the economy).

These distributions could then be used as follows. The probability that the debt-stabilizing primary balance exceeds the actual primary balance would indicate risks to debt sustainability. If this probability were low (say, 5 percent or less), the primary fiscal standard-debt sustainability with high probability, conditional on baseline policies-would be considered satisfied. If higher than that, the country would need to adjust, with the speed of adjustment depending on the risks to sustainability, the state of the economic cycle, and the capacity of monetary policy to offset the contractionary impact of adjustment on the European Union as a whole.

Importantly, a violation of the fiscal standard would generally not imply that debt is unsustainable, only that fiscal adjustment is required to maintain (or return to) debt sustainability with high probability. The only exception would be rare cases (say, happening with probability of less than 5 percent) where an economic shock or the realization of a contingent liability was so large that the adjustment required to prevent an explosive debt path became economically or politically infeasible (as in Greece in 2009-10, for example). Hence, except in those rare cases-when the only way out is a debt restructuring-a finding that the fiscal standard is violated should not, for example, trigger a loss of access to ECB bond purchase facilities.

A stochastic debt sustainability analysis of this type is not an easy exercise to perform: it requires forecasts and distributional assumptions. A notoriously difficult aspect is to capture linkages between the various forecasts, such as feedback from the debt level to the interest rate. That said, researchers and official institutions-including the European Commission, ECB, European Stability Mechanism, and IMF-have developed methods that implement, or at least approximate, the general approach suggested above (Bouabdallah et al. 2017, Debrun et al. 2019, Eichengreen et al. 2018, European Commission 2014, IMF 2021). ${ }^{13}$ And whatever the failing of these models, they are vastly superior, as a predictor of debt distress, to the simple debt and deficit ratios that underlie the current EU fiscal framework.

An important question is whether the fiscal standards should prescribe behavior in cases when debt sustainability is not at risk. As argued in section 4 , debt crises are not the only externality potentially caused by fiscal policy: when ECB interest rates are at the effective lower bound, there could be a demand externality, implying that fiscal policy in member states is collectively too contractionary. And indeed, we have argued that the capacity of the ECB to offset contractionary fiscal policy should be considered when deciding on the speed with which countries should be required to reduce their deficits.

At the same time, our preferred instrument for addressing such a demand externality is fiscal policy not at the level of individual member states but at the EU level, funded by common borrowing. First, this is likely to be more effective in delivering the requisite fiscal impulse. Second, requiring a country

13 The IMF is currently designing a new probabilistic debt sustainability analysis framework whose centerpiece is a "fan chart tool" along the lines described above. 
to increase its deficit-saddling its taxpayers with debt to achieve stimulus that benefits others-is likely to be politically impossible. In contrast, the recently established EU recovery fund, based on common borrowing, has demonstrated the political feasibility of an EU-level fiscal expansion at least in the face of a very large downturn.

As a result, we do not advocate a fiscal standard that would attempt to force member states to run more expansionary policies than they wish to. Our proposed standard would allow members to run any fiscal policy they want, provided they do not put themselves and other members at risk of a debt crisis. ${ }^{14}$

\section{Enforcing Fiscal Standards}

New Zealand's fiscal standards have been enforced primarily through parliamentary and public scrutiny. The law requires the government to publish periodic statements and reports on fiscal policy, including an annual fiscal strategy laying out its fiscal plans in the next four years. In these reports, the government must explain why and how its plans are consistent with the fiscal standards set forth in the law, backed by short- and long-term fiscal projections produced by the Treasury, "which enjoys a great degree of independence from the government, in effect acting as a fiscal council" (Wyplosz 2019, 24). If these explanations are unconvincing, the government risks parliamentary and public backlash. Hence, New Zealand's fiscal framework is "founded on two key planks: transparency and accountability" (New Zealand Treasury 2019).

While this approach appears to have worked well in New Zealand-in a recent comparative analysis, Charles Wyplosz (2019) concludes that New Zealand's fiscal framework has been "highly successful"-public transparency and accountability to national parliaments are unlikely to be sufficient to enforce the EU fiscal framework, since the latter is mainly a response to externalities across member countries. Almost by definition, cross-country externalities are something that national parliaments and public opinion will be insufficiently concerned about. Hence, fiscal standards at the EU level require an additional enforcement channel.

One possible candidate is market discipline. In principle, financial markets might be able to deter governments from overborrowing, through higher interest rates and the prospect of loss of market access before debt reaches dangerous levels. In practice, market discipline is very unlikely to be sufficient. The history of the euro (and financial history more generally) suggests that financial markets tend to first underreact and then suddenly overreact. Both problems can arguably be reduced by providing relevant information to the markets, by making sovereign debt restructuring in the euro area a more credible option, through

14 We recall Erich Kästner's children's classic Emil und die Detektive, set in 1920s Berlin. A character in the book, a boy of perhaps 12 years old nicknamed "der Professor," describes the standard applied to filial conduct in his family as follows: "Ich habe meinem alten Herrn versprochen, nichts zu tun, was unanständig oder gefährlich ist. Und solange ich das Versprechen halte, kann ich machen, was ich will. Ist ein glänzender Kerl, mein Vater" ("I promised my old man not to do anything that is indecent or dangerous. And as long as I keep that promise, I can do what I want. He is a brilliant guy, my father"). What we are proposing is, in effect, the "der Professor" standard for fiscal policy in the European Union. 
Table 1

Options for enforcing EU fiscal standards

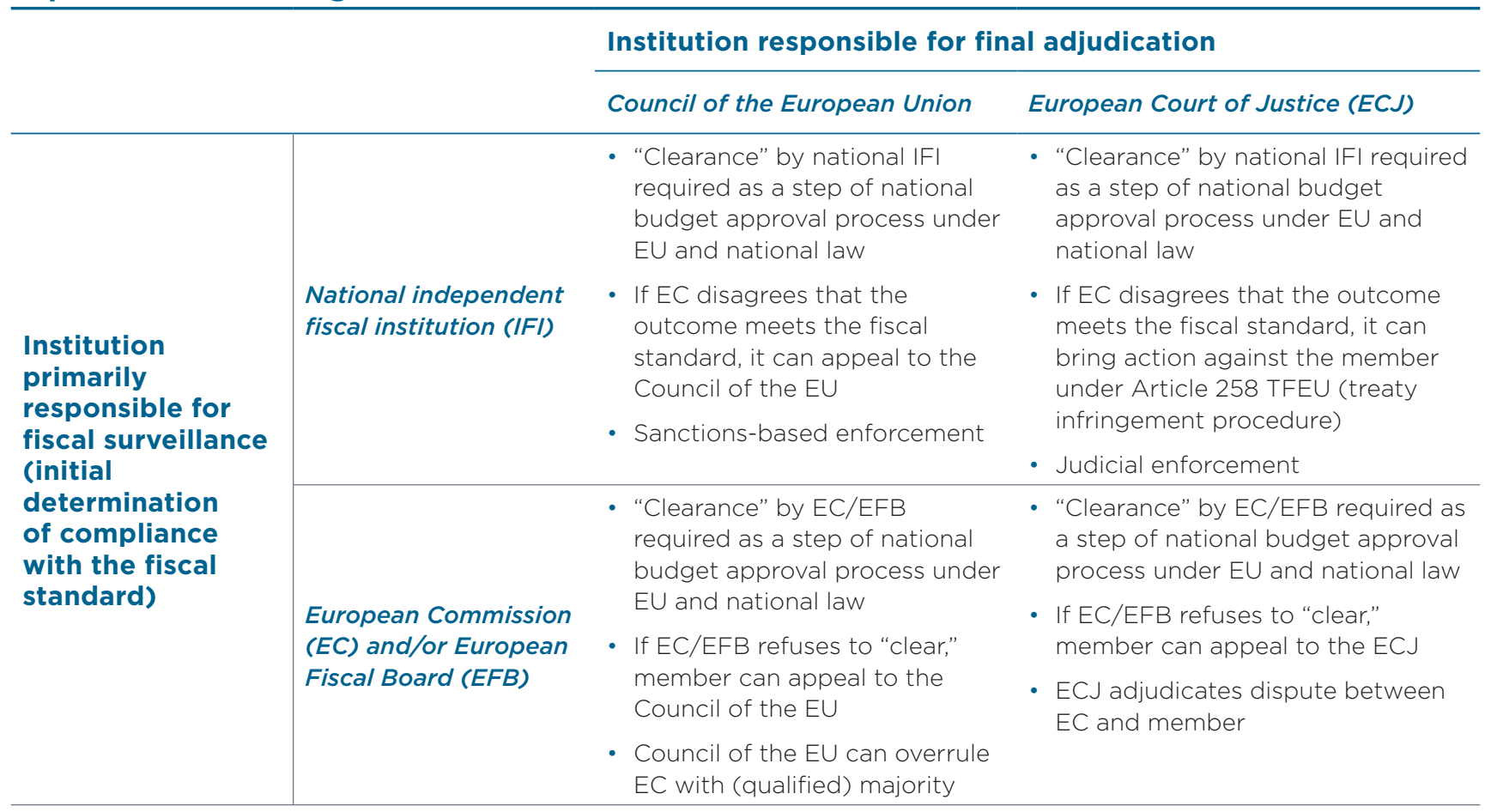

TFEU = Treaty on the Functioning of the European Union

institutions such as the ESM, and policies such as the ECB's OMT. However, some of the required reforms might be a tall order..$^{15}$ The political will to undertake such reforms may be lacking for some time to come.

Consequently, even if one shares the view that markets could be a more prominent source of fiscal discipline in the euro area, they cannot be the only source. Enforcing fiscal discipline will continue to require a formal process, including the designation of an adjudicator. For the purposes of the fiscal framework, there are four main options (summarized in table 1). They differ in terms of (1) who undertakes the initial determination on whether the government complies with the fiscal standards based on criteria and methods described in secondary legislation (box 1) and what triggers EU-level adjudication, and (2) who adjudicates: the Council of the EU or an independent judicial institution such as the European Court of Justice.

- An initial regular determination of whether the standard is met could be undertaken either at the national level, by a national independent fiscal institution (IFI) as proposed by Wyplosz (2019), or at the European level, by the European Commission (EC) and/or the European Fiscal Board (EFB). This institution should be empowered to block or at least delay parliamentary approval of budget legislation.

15 Bénassy-Quéré et al. (2018) argue that these reforms should include not only changes to the legal framework for sovereign debt restructurings but also better financial and fiscal safety nets, including fiscal risk sharing and European deposit insurance, regulation that discourages sovereign exposures of banks, and a euro area safe asset. 
- In the event that the national IFI is tasked with making the initial determination and allows the budget to go forward, the EC could appeal the result to either the Council of the EU, which could decide to impose sanctions on members seen as violating the fiscal standard, or the European Court of Justice (ECJ), by way of a treaty infringement procedure. Hence, the EC would maintain a surveillance role even if the initial determination of whether the standard is met is made by a national IFI.

- In the event that the EC is tasked with making the initial determination and blocks or delays approval, the member state could appeal to a European-level adjudicator. This could be either the Council of the EU, which could overturn the decision of the EC (possibly with a qualified majority), or the ECJ.

The options described in the first column of the table-enforcement via the Council of the EU-are variants of the current enforcement procedure. Compared to the current procedure, the main difference would be a change in national laws in all EU members (possibly coordinated through an EU directive) that gives a specific independent entity-either a national IFI or an EU entitysignificant power in the national budget approval process. This step may not require changes in EU primary legislation (Treaty change), but it may well require changes in national constitutions.

In contrast, the options described in the second column-making the ECJ (or another specialized EU-level judicial institution) the adjudicator of disputes between member states and the Commission-would almost surely require Treaty change. In particular, paragraph 10 of Article 126 explicitly rules out the standard treaty infringement procedure (the power of the EC to "sue" countries violating the Treaty) for the purposes of enforcing the EU prohibition of excessive deficits (Repasi 2016). ${ }^{16}$

Why was the standard legal route ruled out for the purpose of enforcing the fiscal framework? History suggests that this was the political and economic quid pro quo for the decision to adopt ex ante debt and deficit thresholds. In February 1991, the alternates of the Monetary Committee of the European Community (representing finance ministries and central banks) proposed the adoption of reference values for government debt and deficits as a share of GDP but also "recognized that the assessment of government deficits could not consist merely in the mechanical application of these criteria but...would require judgment by the political authorities. The procedure to be followed in the evaluation of excessive deficits was therefore considered to be as important as were the reference values" (Bini Smaghi, Padoa-Schioppa, and Papadia 1994, 28-29). In other words, a "soft" enforcement process involving political judgment was meant to balance, and to some extent offset, the use of "hard" numerical criteria.

Replacing fiscal rules by standards, as proposed in this paper, would eliminate the need for "softening" via the enforcement process. Furthermore, adjudication

16 Paragraph 10 states that "the rights to bring actions provided for in Articles 258 and 259 may not be exercised within the framework of paragraphs 1 to 9 of this Article." Article 258 refers to the so-called treaty infringement procedure, which allows the European Commission to take legal action against a member state before the ECJ when it believes that the member has violated a treaty obligation, while Article 259 gives member states a similar right against another member state. 
through the Council of the EU would lack an essential feature of standards according to the legal literature, namely, an adjudication body that systematically "gives the law content ex post" (Kaplow 1992). The Council is not well placed to play this role, because it may decide politically rather than with a view to creating fiscal standards jurisprudence.

For these reasons we argue for one of the options in the second column of the table: adjudication by the ECJ or a new, designated body (for example, an upgraded version of the European Fiscal Board). Putting the ECJ in charge would require removing paragraphs 3-10 from Article 126 and bringing back the normal treaty infringement procedure in the context of the article. Putting a new body in charge may require deeper treaty change.

Enforcement via an EU-level judicial or quasi-judicial body would need to address three main objections.

First, judicial adjudication can take a long time. In the meantime, the disputed budget would either go ahead (if compliance with the standard was initially assessed at the national level; top right cell of table 1) or be blocked, with the law defining a fallback such as a repeat execution of the preceding year's budget (if the initial compliance is assessed at the European level; bottom right cell of table 1). To reduce the delay prior to final adjudication, the independent adjudicator would need to have the capacity to decide within months. In the case of ECJ adjudication, this would probably require the creation of a specialized chamber (as recently proposed, in the sovereign debt restructuring context, by Grund and Stenström 2019). This would also address the problem that the current ECJ members may lack the economic expertise required to adjudicate a fiscal standard.

Second, there is a concern that judges would dictate decisions that ought to be the prerogative of legislatures. This is valid, but the scope of these decisions would be defined by EU law, which is approved by legislatures. Furthermore, it would not go beyond the restrictions that fiscal rules currently impose on national autonomy, namely, requiring a different fiscal balance from that which member countries might prefer. Finally, the fact that independent bodies decide on matters that are intensely political is not new and is widely accepted in the European Union. For example, the ECJ decides whether national regulation violates single market rules or whether state aid violates competition rules, and has also ruled on the legality of ECB monetary policy (the 2015 Gauweiler and 2018 Weiss judgments).

Third, according to our proposal, the European Commission would remain in its current role of "prosecutor" of fiscal misbehavior, even if the adjudication role is assigned to an independent body. Given the EC's political nature, there is a risk that this may lead to underenforcement. However, there is no obvious lack of Commission enthusiasm for enforcing the Treaty in other areas. Complaints about "political" behavior on the part of the Commission tend to focus on its role in enforcing the fiscal rules, as opposed to, for example, competition or single market rules. This suggests that the problem may lie less with the political nature of the Commission but rather with Article 126 (paragraphs 3-10), which explicitly stipulates a political process for enforcing fiscal rules-an approach unique to the 
fiscal area. ${ }^{17}$ Alternatively (or in addition), it is possible that the political nature of the Commission becomes an issue only when national political stakes are very high, as in fiscal matters. This would argue for the top-right variant of the options laid out in table 1, in which the initial determination on the legality of a budget proposal is undertaken by a national IFI.

In the event that EU-level judicial enforcement is politically unachievableeither because it implies that European judges could ultimately overrule parliaments in fiscal matters or because of the required EU Treaty change-one of the two variants in the left column of table 1 could be considered. In both of these variants, enforcement would be beefed up from the current practice, as either a national IFI or the European Commission would obtain the power to block (or at least delay, pending adjudication) a draft budget. At the same time, the Council of the EU would remain the EU-level enforcer. Furthermore, in the top-left variant, the European Commission would continue in its current role of reporting to the Council whether the member states' deficits are excessive, without the power to block national legislation.

While this option would require changes in both EU secondary legislation and national laws - to replace EU fiscal rules with a fiscal standard and empower national IFIs, respectively-it might not require Treaty change. Retaining the reference values of 3 percent deficit and 60 percent debt-to-GDP ratio, anchored in the Treaty, might conceivably be consistent with the fiscal standards approach proposed in this paper, so long as the decisions on whether the deficit ratio is "close" (enough) to the reference value and on whether the debt ratio is "sufficiently diminishing and approaching the reference value at a satisfactory pace" are governed by the type of stochastic debt sustainability analysis and other methods discussed in this paper. ${ }^{18}$ These methods would in turn need to be anchored in new EU secondary legislation, as described in box 1.

\section{CONCLUSION}

European fiscal rules were conceived in the early 1990s as a way of addressing adverse debt externalities arising across euro area members. Such externalities arose both because debt accumulation might put pressure on the ECB to inflate and because of adverse spillovers in the event of a debt crisis. The fiscal rules were meant to maintain public debt at safe levels while giving members adequate space to conduct fiscal stabilization policy.

Almost 30 years later, there is a wide consensus among economists and policymakers in the European Union that the fiscal rules have not been very successful and require reform. We agree. We disagree, however, with the

17 Note also that restoring the normal judicial enforcement channel in the context of Article 126 would not only give the Commission the right to open a case against a member (Article 258 TFEU) but also allow members to take legal action against other members if the Commission failed to do so (Article 259 TFEU). This would limit the extent to which the Commission could remain inactive.

18 Article 126 (2) allows member states to exceed the reference value for the deficit ratio so long as "either the ratio has declined substantially and continuously and reached a level that comes close to the reference value, or, alternatively, the excess over the reference value is only exceptional and temporary and the ratio remains close to the reference value." The reference values are specified in a protocol on the excessive deficit procedure annexed to the Treaty. 
approach taken by most reform proposals, which focus on simplifying the fiscal rules and making them less procyclical. Instead, the problem is with the very concept of fiscal rules.

The essence of our argument is that the attempt to write such rules is bound to be a fool's errand. Whether debt is at risk of becoming unsustainable does not just depend on debt and deficit levels but on a host of uncertain economic and political factors. Fiscal rules, even complex ones, cannot account for this uncertainty because it is impossible to predict and specify the relevant contingencies ex ante. Rules are thus bound to lead to mistakes, constraining fiscal policy either too much or too little.

The alternative to rules is standards. Unlike rules, standards distinguish good from bad behavior in qualitative rather than numerical terms. Whether the standard is satisfied is determined ex post, at the point of application. This allows an adjudicator to draw on a much larger information set than typically enters rules. It also allows room for judgment.

Article 126 (1) of the Treaty on the Functioning of the European Union, in which the fiscal rules are anchored, already establishes a fiscal standard: "Member states shall avoid excessive government deficits." Rather than inventing a complex system of rules to determine what is excessive, an independent bodyeither a national IFI or the European Commission, or both in sequence-should analyze the fiscal position of members using stochastic debt sustainability analysis, based on criteria and procedures laid out in EU secondary legislation. If it finds that a member state's debt is not sustainable with high probability, the member state should be required to undertake fiscal adjustment, at a speed that balances the output costs of adjustment with the risks of delay.

To be successful, standards require an effective enforcement process. Ideally this would take the form of adjudication of disputes between the European Commission and member states by an independent body, such as the ECJ or a specialized EU-level court. Alternatively, the existing enforcement mechanism, in which the Council adjudicates disputes, could be strengthened by allowing national IFIs or the European Commission to block (or delay, pending adjudication) budgets that do not comply with the fiscal standards.

The proposals of this paper would mark a large departure from the status quo. EU secondary legislation that makes up the Stability and Growth Pact would need to be replaced, and national laws would need to be changed to give either national IFIs or the European Commission a stronger say in the budgetary approval process. Putting an EU judicial body in charge of adjudication would require a Treaty change. But in an environment in which the COVID-19 crisis has already led to the suspension of such rules as well as common and national fiscal action that was previously unthinkable, the opportunity to rethink the EU fiscal framework in a fundamental way should not be squandered. Successive waves of reform have not made much of a difference. It is time to question the premises of the framework itself. 


\section{REFERENCES}

Andrle, Michal, John Bluedorn, Luc Eyraud, M. Tidiane Kinda, Petya Koeva-Brooks, Gerd Schwartz, and Anke Weber. 2015. Reforming Fiscal Governance in the European Union. Staff Discussion Note No. 15/9. Washington: International Monetary Fund.

Beetsma, Roel, Niels Thygesen, Alessandro Cugnasca, Eloïse Orseau, Polyvios Eliofotou, and Stefano Santacroce. 2018. Reforming the EU fiscal framework: A proposal by the European Fiscal Board. VoxEU.org, October 26.

Bénassy-Quéré, Agnès, Markus K. Brunnermeier, Henrik Enderlein, Emmanuel Farhi, Marcel Fratzscher, Clemens Fuest, Pierre-Olivier Gourinchas, Philippe Martin, Jean Pisani-Ferry, Hélène Rey, Isabel Schnabel, Nicolas Véron, Beatrice Weder di Mauro, and Jeromin Zettelmeyer. 2018. Reconciling Risk Sharing with Market Discipline: A Constructive Approach to Euro Area Reform. Policy Insight No. 91. London: Centre for Economic Policy Research.

Bini Smaghi, Lorenzo, Tommaso Padoa-Schioppa, and Francesco Papadia. 1994. The Transition to EMU in the Maastricht Treaty. Princeton Essays in International Finance No. 194, November.

Blanchard, Olivier. 2019. Public Debt and Low Interest Rates. American Economic Review 109, no. 4: 1197-229.

Bohn, Henning. 1998. The Behavior of U.S. Public Debt and Deficits. Quarterly Journal of Economics 113, no. 3: 949-63.

Bouabdallah, Othman, Cristina Checherita-Westphal, Thomas Warmedinger, Roberta de Stefani, Francesco Drudi, Ralph Setzer, and Andreas Westphal. 2017. Debt Sustainability Analysis for Euro Area Sovereigns: A Methodological Framework. Occasional Paper Series No. 185. Frankfurt: European Central Bank.

Claeys, Grégory, Álvaro Leandro, and Zsolt Darvas. 2016. A Proposal to Revive the European Fiscal Framework. Policy Contribution 2016/O7. Brussels: Bruegel.

Constâncio, Vítor. 2020. The Return of Fiscal Policy and the Euro Area Fiscal Rule. Comparative Economic Studies 62: 358-72.

Darvas, Zsolt, Philippe Martin, and Xavier Ragot. 2018. European Fiscal Rules Require a Major Overhaul. Policy Contribution no. 18. Brussels: Bruegel.

Debrun, Xavier, Jonathan D. Ostry, Tim Willems, and Charles Wyplosz. 2019. Public Debt Sustainability. In Sovereign Debt: A Guide for Economists and Practitioners, ed. Ali Abbas, Alex Pienkowski, and Kenneth Rogoff. New York: Oxford University Press.

Deroose, Servaas, Nicolas Carnot, Lucio R. Pench, and Gilles Mourre. 2018. EU fiscal rules: Root causes of its complexity. VoxEU.org, September 14.

Eichengreen, Barry, Emilios Avgouleas, Ugo Panizza, Miguel Poiares Maduro, Richard Portes, Beatrice Weder di Mauro, Charles Wyplosz, and Jeromin Zettelmeyer. 2018. Independent Report on the Greek Official Debt. Policy Insight No. 92. London: Centre for Economic Policy Research.

Ehrlich, Isaac, and Richard Posner. 1974. An Economic Analysis of Legal Rulemaking. Journal of Legal Studies 3, no. 1: 257-86.

European Commission. 2014. Assessing Public Debt Sustainability in EU Member States: A Guide. ECFIN Occasional Papers No. 200. Brussels.

European Commission. 2019. Vade Mecum on the Stability and Growth Pact. Institutional Paper 101. Brussels.

EFB (European Fiscal Board). 2019. Assessment of EU fiscal rules with a focus on the six and two-pack legislation. Brussels. 
Eyraud, Luc, Vítor Gaspar, and Tigran Poghosyan. 2017. Fiscal Politics in the Euro Area. Working Paper No. 17/18. Washington: International Monetary Fund.

Feld, Lars, Christoph Schmidt, Isabel Schnabel, and Volker Wieland. 2018. Refocusing the European fiscal framework. VoxEU.org, September 12.

Gaspar, Vítor. 2020. Future of fiscal rules in Europe. Keynote speech at Workshop on "Fiscal Rules in Europe: Design and Enforcement" at DG ECFIN, January 28, Brussels.

Grund, Sebastian, and Mikael Stenström. 2019. A Sovereign Debt Restructuring Framework for the Euro Area. Fordham International Law Journal 42: 795-845.

Hart, H. L. A. 1961. The Concept of Law (Clarendon Law Series). Oxford, UK: Oxford University Press.

Hart, H. L. A. 2013. Discretion. Harvard Law Review 127, no. 2: 652-65.

Hatchondo, Juan Carlos, Leonardo Martinez, and Francisco Roch. 2012. Fiscal Rules and the Sovereign Default Premium. Working Paper No. 12/30. Washington: International Monetary Fund.

IMF (International Monetary Fund). 2021. Review of the Debt Sustainability Framework for Market Access Countries. Policy Paper No. 2021/003. Washington: International Monetary Fund.

James, Harold. 2012. Making the European Monetary Union. Cambridge, MA: Harvard University Press.

Kaplow, Louis. 1992. Rules versus Standards: An Economic Analysis. Duke Law Journal 42: 557-629.

Lerner, Abba P. 1943. Functional Finance and the Federal Debt. Social Research 10, no. 1: 38-51.

Lorenzoni, Guido, and Iván Werning. 2019. Slow Moving Debt Crises. American Economic Review 109, no. 9: 3229-63.

New Zealand Government. 2020. Wellbeing Budget 2020. Rebuilding Together. Wellington: Government of New Zealand.

New Zealand Treasury. 2015. An Introduction to New Zealand's Fiscal Policy Framework. Wellington: Government of New Zealand.

New Zealand Treasury. 2019. A Guide to the Public Finance Act. Wellington: Government of New Zealand.

Odendahl, Christian. 2015. We Don't Need No Federation: What a Devolved Eurozone Should Look Like. London: Centre for European Reform.

Pound, Roscoe. 1922. An Introduction to the Philosophie of Law. New Haven: Yale University Press.

Rachel, Łukasz, and Lawrence H. Summers. 2019. On Falling Neutral Real Rates, Fiscal Policy, and the Risk of Secular Stagnation. Brookings Papers on Economic Activity. BPEA Conference Drafts, March 7-8. Washington: Brookings Institution.

Repasi, René. 2016. Implementation of the Lisbon Treaty - Improving Functioning of the EU: Economic and Monetary Policy. Study for European Parliament's Committee on Constitutional Affairs, Brussels.

Schlag, Pierre J. 1985. Rules and Standards. 33 UCLA Law Review 379: 1-28.

Sunstein, Cass. 1995. Problems with Rules. California Law Review 83, no. 4: 952-1026.

Wyplosz, Charles. 2005. Fiscal Policy: Institutions versus Rules. National Institute Economic Review 191, no. 1: 64-78.

Wyplosz, Charles. 2019. Fiscal Discipline: From Theory to Practice. In European Fiscal Board Workshop 2019: Independent Fiscal Institutions in the EU Fiscal Framework: 8-33. 


\section{INTERNATIONAL ECONOMICS}

(c) 2021 Peterson Institute for International Economics. All rights reserved.

This publication has been subjected to a prepublication peer review intended to ensure analytical quality. The views expressed are those of the authors. This publication is part of the overall program of the Peterson Institute for International Economics, as endorsed by its Board of Directors, but it does not necessarily reflect the views of individual members of the Board or of the Institute's staff or management.

The Peterson Institute for International Economics is a private nonpartisan, nonprofit institution for rigorous, intellectually open, and indepth study and discussion of international economic policy. Its purpose is to identify and analyze important issues to make globalization beneficial and sustainable for the people of the United States and the world, and then to develop and communicate practical new approaches for dealing with them. Its work is funded by a highly diverse group of philanthropic foundations, private corporations, and interested individuals, as well as income on its capital fund. About 35 percent of the Institute's resources in its latest fiscal year were provided by contributors from outside the United States.

A list of all financial supporters is posted at https://piie.com/sites/default/files/supporters.pdf. 